Enes Karić

\title{
DJELO OZBILJNE AKADEMSKE UPUĆENOSTI I PLEMENITOG DIJALOŠKOG STAVA ${ }^{1}$
}

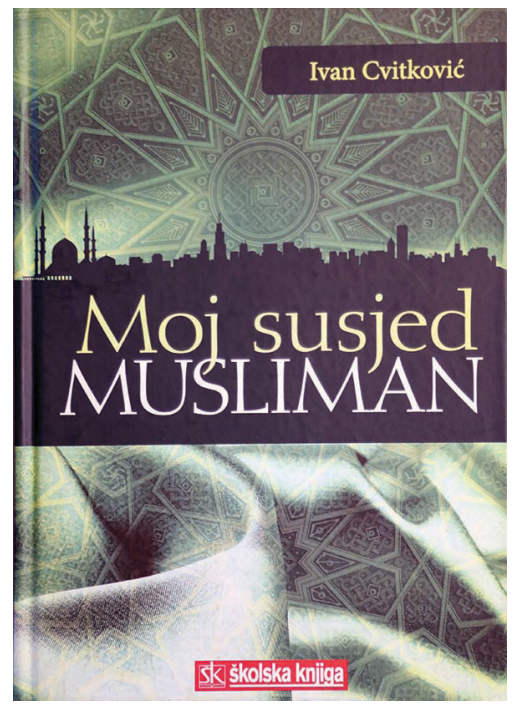

Akademika Ivana Cvitkovića ne treba posebno predstavljati kao vodećeg sociologa religije u Bosni i Hercegovini, kao i u zemljama naše nekadašnje zajedničke države, SFR Jugoslavije, pa i šire. Njegovo djelo i akademski rad visoko su ocijenjeni, a njegovi stavovi o društvenoj ulozi religija i religijama bliskih svjetonazora uvaženi. Akademik Cvitković se već više od četiri decenije naučno i upućeno, prevalentno sociološki, bavi fenomenima religije u kontekstu naše savremenosti i na razinama identiteta, društva, politike, međukonfesionalnih odnosa, multikulturalne saradnje, konfliktnih epoha itd.

Cvitkovićeva knjiga Moj susjed musliman koja se nedavno pojavila u Zagrebu - po tematima kojima se bavi, kao i načinu na koji autor promišlja najvažnija pitanja o islamu i muslimanima danas u svijetu, u Evropi i u Bosni i Hercegovini - najbolje je djelo iz ove oblasti koje se kod nas pojavilo u protekla dva ili tri desetljeća.

Sadržaj ove knjige akademik Cvitković je profilirao u skladu sa potrebama konceptualiziranja jednog opsežnog sveučilišnog udžbenika o savremenim kretanjima u islamu, namijenjenog za studente sociologije i srodnih društve-

\footnotetext{
${ }^{1}$ Prikaz knjige Moj susjed musliman. Preporod, br. 16/17, 2012, str. 44. O knjizi su pisali i Mirko Pejanović u časopisu Pregled, Fikret Karčić u Temama, Niš, br. 1/2012, Ivana Divković u listu Epicentar Slavonije, Osijek, Dino Abazović u Odjeku, Sarajevo, br. 3-4/2012, Zorica Kuburić u časopisu Religija\&tolerancija, Novi Sad, br. 16/2011, Fahrudin Novalić u časopisu Behar, 28. 9. 2013, Ivan Anđelić u Oslobođenju, Sarajevo, 12. 11. 2011. Zanimljivo je da je taj tekst nepoznata osoba ubacila u moj poštanski sandučić (vjerojatno misleći da ne čitam Oslobođenje) i u njemu podvukla sljedeću rečenicu: “...naslov knjige Moj susjed musliman, koji govori o autoru kao istinskom intelektualcu s osjećajem topline prema svom bližnjem. Autor se rodio u Mostaru, a čitav svoj radni vijek živi u Sarajevu."
} 
nih nauka. U samom Uvodu Cvitković ističe da je islam "od svih poznatijih živih religija (budizma, hinduizma, taoizma, šintoizma...) evropskim kršćanima najbliži. Štoviše - on je često religija prvih susjeda, u mnogim evropskim državama u kojima kršćani čine većinu, to je druga religija po brojnosti sljedbenika" (str. 8). Potom se Ivan Cvitković usmjerava, izlaganjem sedamnaest velikih cjelina svoje knjige, na sljedeće teme: Šta bi Evropljanin trebao znati o islamu?; Stanje među muslimanima; Politička kretanja među muslimanima; Sličnosti i razlike u vjerovanjima kršćana i muslimana; Moralne vrijednosti, pouke i poruke islama i kršćanstva; Odnos kršćana na Zapadu prema islamu i muslimanima; Odnos muslimana prema Zapadu, kršćanstvu i kršćanima; Islam i kršćanstvo u kontekstu demokracije i vjerskih sloboda; Muslimani u Evropi i Evropskoj Uniji; "Evropski islam” ili islam u Evropi; Konflikti i/ili nesporazumi; Kontroverze oko pojma "džihad"; Marama, zašto ne; Društveni status muslimanke; Kontroverze oko vehabizma; U terorizmu je religija oteta; Šta raditi? Ukratko, ovo su naslovi poglavlja obimne i problemski razuđene knjige Moj susjed musliman profesora Ivana Cvitkovića.

Svako poglavlje ima jedan, pristupačnim akademskim jezikom saopćen, informativni dio. Autor Cvitković raskriva svome (kršćanskom, ali i sekularnom) čitatelju, štaviše studentu kao i profesoru društvenih nauka, šta jesu načela islama.

Cvitković djeluje na ovim stranicama s pravom kao autoritativno pero. On educira svoje (zapadno) čitateljstvo, tako kaže: "Podsjetimo, 'muhamedanci' je uvredljiv naziv za muslimane nastao još u vrijeme Križarskih ratova. Analogijom 'Krist' - 'kršćani' tražio se izlaz u nazivu 'Muhamed' - 'muhamedanci'! Međutim, analogije u komparativnim pristupima religijama i religijskim identitetima su neizvodive." (str. 10)

Također, u prvim poglavljima svoga vrijednog djela Ivan Cvitković daje relevantne i respektabilne informacije o: a) izvorima, b) obredima, c) moralnim naučavanjima, d) historijskim razvojima, e) društvenim i f) savremenim kretanjima islama.

Da bi vjerodostojno opisao vrijeme koje obilježava "njegova susjeda muslimana", autor Cvitković je posebnu ravan svoje knjige posvetio savremenim debatama između "Zapada i islama" i napetostima između tog ideologijski konstruiranog dvojca te debatama koje se najčešće aktueliziraju u današnjim političkim, geostrategijskim i ideološko-religijskim opservacijama.

"Muslimanski je svijet zadnjih dvjesto godina bio pod utjecajem zapadnih vrjednota i modernosti", tvrdi Cvitković (str. 115) i donosi kratke ekskurse o sekularizaciji, nastanku građanske Evrope, reperkusijama svega toga na rasprostranjene islamske i muslimanske kulture. Cvitković na vrlo razložan 
način, gotovo kroz cijelu knjigu, prati fenomen "stvaranja negativne slike o islamu" (npr. na str. 117) te time i negativne slike o "njegovom susjedu muslimanu", ali jednako tako, odmjereno i uravnoteženo, prati i "izmišljanje Zapada" na muslimanskoj strani. Poziva se na tvrdnju S. Žižeka: "U muslimanskim zemljama na djelu je određena ideološka vizija Zapada koja iskrivljuje pravu sliku o Zapadu u ništa manjoj mjeri (iako na drugačiji način) nego što orijentalizam iskrivljuje sliku o Orijentu."

Cvitković na ovim dionicama knjige predočava koje su to teme u samoj srži debate između "Zapada" i "islama" danas te koje rasprave saodređuju "naše gledanje na muslimane". Velike "nutarnje teme" ove Cvitkovićeve knjige su: Muslimanska emigracija izazvana ekonomskim neskladom čitavih civilizacijskih svjetova, najnoviji ratovi Zapada u tradicionalnim muslimanskim zemljama, "posvjetovljenje" koje preplavljuje tradicionalne vjere, pojava tzv. "islamske narcisoidnosti", islamofobija na Zapadu, s jedne, i sve lošiji položaj kršćana u zemljama u kojima postoje muslimanske većine, s druge strane, (ne)tolerancija kroz povijest i (ne)tolerancija danas itd.

U elaboriranju ne samo ove već gotovo svih tema u svojoj knjizi, akademik Cvitković se poziva na stotine autora, donosi na desetine, pa i stotine citata i parafraza današnjih angažiranih ili svojim glasom na drugi način prisutnih mislilaca i teoretičara. Naš je dojam da Cvitković uravnoteženo donosi poglede ljudi koje je kao svjedoke prizvao na stranice svoje knjige; također, u osnovi koju je često postavio u ovim svojim raspravama, ta mišljenja drugih služe autoru kao snažna potka.

Unutar mnogih tema ove knjige, Ivan Cvitković u opću tematiku islama impregnira i Bosnu i Hercegovinu i bosanskohercegovačke muslimane. S posebnim se zanimanjem čitaju ulomci i citati (npr. od reisu-l-uleme Mustafe Cerića, Mustafe Spahića, Alije Isakovića, Irfana Ljubijankića, Muhameda Filipovića...) koji su kazani u ratu i obilježava ih doba rata 1992-1995. godine. Sada, u vremenima izglednoga mira, riječi izrečene u stanju totalne opkoljenosti zvone posebnim zvonom. Inače, tema Bosne i Hercegovine u ovoj knjizi ne zanemaruje ni sadašnjost, a ni prošlost. Sinhronija i dijahronija je jedna od važnih kvaliteta ove Cvitkovićeve knjige. Time je autor htio pokazati "svoga susjeda muslimana" i po dubini, u vremenima Osmanskog carstva, kad je taj susjed bio carski privilegiran, ali ga je prikazao i kao susjeda u vremenima evropskog nastupanja u BiH. Ivan Cvitković tako o mjestu Bošnjaka u današnjoj Evropi kaže: “...da nije riječ ni o kakvom stranom tijelu u njezinu organizmu, nego čak o jednom od europskih, slavenskih naroda (Bošnjaci) koji svojom kulturom i tradicijom, iskustvima reformacije, može samo obogatiti kulturni milje Europe.” (str. 130) 
Cvitković je također u bavljenju i ophođenju prema povijesnim dubinama oprezan i uravnotežen. Kad je npr. riječ o "prisilnoj islamizaciji”, Cvitković se poziva na Mariju Todorovu: “...iako je bilo prisilnog preobraćanja na islam, u većini slučajeva ono (preobraćenje) je bilo nenasilno, eufemistički rečeno dobrovoljno..." (str. 123).

Imajući stalno na umu "svoga susjeda muslimana", na mnogo mjesta Cvitković se bavi najnovijim razvojima na islamskoj sceni u BiH. Smatramo veoma zanimljivim autorova tumačenja da je aroma "turske kultur(al)ne zone" obilježavala islamsku tradiciju Bošnjaka sve do 1990. godine, a da je potom vidljiv "prodor iranskog i arapskog (osobito saudijskog) islama..." (str. 130). Pogled na tzv. vehabizam u ovoj je knjizi prisutan na nekoliko mjesta, posvećeno mu je i jedno kraće poglavlje. U vezi s ovim treba reći da je praktički sve cjeline Cvitkovićeve knjige koje se odnose na bosanskohercegovačke muslimane (u kontekstu povijesne $\mathrm{BiH}$ ) moguće čitati i kao opservacije kulturalnih ozračja i civilizacijskih smjena "kroz koja je prolazio moj susjed musliman".

Recimo na kraju ovog veoma reduciranog prikaza vrijednog djela Ivana Cvitkovića da ovu njegovu knjigu za čitanje te studentsko i sveučilišno revnovanje posebno preporučuje i to što je ozbiljno obradio, u različitim kontekstima: odnose ljudskih prava i današnjih teologija, statuse demokratije u tradicionalnim vjerničkim poimanjima, statuse vjerskih sloboda u današnjem Sredozemnom bazenu, odnose politike i religije, tretman religije (napose islama) u medijima, plime današnjih svjetonazornih konflikata itd.

I onda kad ima mjesta u ovoj knjizi o kojima se s akademikom Cvitkovićem ne želimo složiti, ostaje dojam da o njima možemo otvoriti ozbiljan dijalog. Knjiga Moj susjed musliman je, doista, vrijedan doprinos dijalogu i kao takva pristaje instituciji bosanskohercegovačkog susjedstva i komšiluka. 